\title{
Spectrophotometric Determination of Chromium in Steel with 4-(2- Thiazolylazo)-Resorcinol (TAR) Using Microwave Radiation
}

\author{
Luciene S. de Carvalho ${ }^{a, b}$, Antônio Celso S. Costa ${ }^{a}$, Sérgio L. C. Ferreira ${ }^{a}$ and \\ Leonardo S. G. Teixeira ${ }^{*, a, b}$ \\ ${ }^{a}$ Instituto de Química, Universidade Federal da Bahia, Campus Universitário da Federação, \\ 40170-290 Salvador - BA, Brazil \\ ${ }^{b}$ Departamento de Engenharia e Arquitetura, Universidade Salvador, Unifacs, Av. Cardeal da Silva 132, \\ 40220-141 Salvador - BA , Brazil
}

\begin{abstract}
Um método espectrofotométrico foi desenvolvido para determinação de Cr(III) com 4-(2thiazolilazo)-resorcinol. $\mathrm{Cr}$ (III) reage lentamente com TAR em pH 5,7 formando um complexo vermelho. A formação do complexo pode ser acelerada pela irradiação de energia de microondas na mistura reacional. A absorvância atinge seu máximo após 5 min de irradiação e permanece estável por pelo menos $24 \mathrm{~h}$. Brometo de N-cetil-N,N,N-trimetilamônio (CTAB) foi usado para aumentar a sensibilidade e solubilização do sistema. $\mathrm{O}$ método permitiu a determinação de cromo na faixa de concentração entre 0,050 e $3,0 \mu \mathrm{g} \mathrm{mL}^{-1}\left(9,62 \times 10^{-7}\right.$ a $\left.5,77 \times 10^{-5} \mathrm{~mol} \mathrm{~L}^{-1}\right)$ com absortividade molar de $2,73 \times 10^{4} \mathrm{~L}^{-1} \mathrm{~mol}^{-1} \mathrm{~cm}^{-1}$ e limite de detecção de $17 \mathrm{ng} \mathrm{mL}^{-1}\left(3,3 \times 10^{-7} \mathrm{~mol} \mathrm{~L}^{-1}\right)$ em $545 \mathrm{~nm}$. A seletividade foi melhorada com o uso de EDTA e citrato como agentes mascarantes. Fe(III) interfere e deve ser extraído previamente, se presente na amostra. O método proposto foi aplicado com sucesso na determinação de cromo em amostras de aço. A precisão (R.S.D. < 2\%) e a exatidão obtidas foram satisfatórias.
\end{abstract}

A spectrophometric method for the determination of $\mathrm{Cr}$ (III) with 4-(2- thiazolylazo)-resorcinol was developed. $\mathrm{Cr}$ (III) slowly forms a red complex with TAR at $\mathrm{pH}$ 5.7. Irradiating the reacting mixture with microwave energy can accelerate the complex formation. The absorbance reached its maximum with $5 \mathrm{~min}$ of irradiation and remained stable, at least, for $24 \mathrm{~h}$. N-cetyl-N,N,Ntrimethylammonium bromide (CTAB) was used for increasing the sensitivity and solubility of the system. The method allowed the determination of chromium ranging from 0.050 to $3.0 \mu \mathrm{g} \mathrm{mL}^{-1}(9.62$ $\mathrm{x} 10^{-7}$ to $5.77 \times 10^{-5} \mathrm{~mol} \mathrm{~L}^{-1}$ ) with a molar absorptivity of $2.73 \times 10^{4} \mathrm{~L}^{-1} \mathrm{~mol}^{-1} \mathrm{~cm}^{-1}$ and a detection limit of $17 \mathrm{ng} \mathrm{mL}^{-1}\left(3.3 \times 10^{-7} \mathrm{~mol} \mathrm{~L}^{-1}\right)$ at $545 \mathrm{~nm}$. The selectivity was improved by using EDTA and citrate as masking agents. Fe(III) interferes and must be extracted previously, if present in the sample. The proposed method has been successfully applied to the determination of chromium in steel. The precision (R.S.D. <2\%) and accuracy were satisfactory.

Keywords: chromium, TAR, spectrophotometric, microwave radiation, steel

\section{Introduction}

The most important application of chromium in the metallurgic industry is its use as an alloying element in steels. In these materials, chromium contributes to increase the hardness, tempering and oxidation resistance. ${ }^{1}$

Very few methods for chromium determination are based on the complex formation with $\mathrm{Cr}(\mathrm{III})$ in aqueous solution. ${ }^{2}$ However spectrophometric determination of chromium(III) invariably involves heating the reactants with reflux. This is probably due to the slow reactions of

\footnotetext{
* e-mail: leonardoteixeira@unifacs.br
}

chromium(III) aquocomplexes, $\left[\mathrm{Cr}\left(\mathrm{H}_{2} \mathrm{O}\right)_{6}\right]^{3+} .^{3}$ The time required for heating the reactants varies from 5 to $130 \mathrm{~min}$, depending on the reagent employed. Characteristics of previously spectrophotometric methods for chromium determinations are summarized in Table 1. ${ }^{2-6}$

Thiazole azo compounds have attracted much attention, as they are sensitive chromogenic reagents in addition to being important complexing agents. These dyes have been useful in spectrophotometric determinations due to their good selectivity and sensitivity over a wide range of $\mathrm{pH}$ and because they are relatively easy to synthesize and purify. ${ }^{7}$ Among various thiazolylazo derivatives, 1-(2-thiazolylazo)-2-napthol (TAN $)^{8}$ and 4-(2- 
Table 1. Characteristics of previously spectrophotometric methods for chromium determination

\begin{tabular}{lccccc}
\hline Reagent & Linear range/ $\mathrm{mg} \mathrm{L}^{-1}$ & Molar absorptivity/ L mol${ }^{-1} \mathrm{~cm}^{-1}$ & Relative standard deviation/ \% & Heating time/ min & Ref. \\
\hline EDTA & $6.0-160$ & $-\bar{x}$ & 0.6 & 30 \\
5-Br-DMPAP & $0.02-0.56$ & $7.8 \times 10^{4}$ & 2 & 5 \\
PAR & - & $1.7 \times 10^{4}$ & - & 1.25 & 3 \\
PAN & $0.3-2.0$ & $7.93 \times 10^{4}$ & - & 35 & 4 \\
Br-PADAP & - & & & 5 & 40 \\
\hline
\end{tabular}

thiazolylazo)resorcinol (TAR) ${ }^{9}$ have been reported for spectrophotometric determination of chromium(III). The previously method reported by Subrahmanyam and Eshwar ${ }^{9}$ with TAR requires 45 min of heating in a boiling water bath and addition of tert-butyl alcohol because some precipitate was observed after the complex formation.

Microwave energy has been applied to the field of chemistry in recent years, primarily dealing with rapid sample dissolution in analytical chemistry and acceleration of reactions in organic chemistry. ${ }^{10,11}$ In addition, microwave irradiation can be used to accelerate some colour-forming reactions for spectrophotometric determinations. ${ }^{12}$ Spectrophotometric determination of chromium in catalyst using EDTA as the colour-forming reagent and microwave radiation has been proposed by the authors. ${ }^{13}$

In this paper, a simple and rapid method involving microwave radiation is described for the determination of chromium using TAR as spectrophotometric reagent. The method was used for the determination of chromium in steel samples.

\section{Experimental}

\section{Reagents}

All reagents were of analytical grade quality and freshly distilled and deionized water was used.

$1.92 \times 10^{-2} \mathrm{~mol} \mathrm{~L}^{-1}$ chromium stock solution $(1000 \mu \mathrm{g}$ $\mathrm{mL}^{-1}$ ) was prepared by dilution of standard solution (Merck, $\mathrm{CrCl}_{3}$ in $4.2 \% \mathrm{HCl}$ ) with water. Chromium reference solutions were prepared by dilution of the stock solution with water.

$4.51 \times 10^{-4} \mathrm{~mol} \mathrm{~L}^{-1} 4$-(2- thiazolylazo)resorcinol (TAR) was prepared by dissolving $0.1 \mathrm{~g}$ TAR (Aldrich) in $100 \mathrm{~mL}$ of ethanol.

Complexing solution. Prepared by dissolving $1.0 \mathrm{~g}$ of ethylenediamine tetraacetic acid (EDTA, Merck) and $1.0 \mathrm{~g}$ of sodium citrate (Merck) in $100 \mathrm{~mL}$ of water.

$\mathrm{N}$-cetyl-N,N,N-trimethylamonium bromide (CTAB) solution $0.025 \mathrm{~mol} \mathrm{~L}^{-1}$ was prepared by dissolving $1.0 \mathrm{~g}$ of CTAB (Merck) in $100 \mathrm{~mL}$ of water.
Buffer solution ( $\mathrm{pH}$ 5.7) was prepared by mixing a trihydrate sodium acetate solution $1.0 \mathrm{~mol} \mathrm{~L}^{-1}$ and glacial acetic acid $1.0 \mathrm{~mol} \mathrm{~L}^{-1}$ until the required $\mathrm{pH}$.

Hydroxylammonium chloride solution $2 \%(\mathrm{~m} / \mathrm{v})$ was prepared by dissolving $2.0 \mathrm{~g}$ of hydroxylammonium chloride (Merck) in $100 \mathrm{~mL}$ of water.

\section{Apparatus}

Spectrophotometric measurements were made in a Varian Cary 1E UV-Vis spectrophotometer with $1.00 \mathrm{~cm}$ glass cells. The $\mathrm{pH}$ measurements were performed with a ANALYSER $300 \mathrm{pH}$ meter. A domestic microwave oven (Sanyo 700) with $2450 \mathrm{MHz}$ frequency and $700 \mathrm{~W}$ (maximum power) was used for heating the sample solutions.

\section{Sample preparation}

A $0.25 \mathrm{~g}$ amount of each steel sample was previously weighed and placed in a conical flask to which $10 \mathrm{~mL}$ of concentrated nitric acid and $2 \mathrm{~mL}$ of concentrated hydrochloric acid were added. The system was heated up to promote the sample dissolution. The dissolved sample was placed in a volumetric flask and the volume was filled to $250 \mathrm{~mL}$ with water. Aliquots of $5.00 \mathrm{~mL}$ were placed into $100 \mathrm{~mL}$ separating funnels. Then, $50.0 \mathrm{~mL}$ of $\mathrm{HCl} 7$ mol L ${ }^{-1}$ were added and shaken with $25.0 \mathrm{~mL}$ of methyl isobutyl ketone (MIBIK) for $5 \mathrm{~min}$ for iron extraction and allowed the phases to separate. The aqueous solution was adjusted with $\mathrm{NaOH}$ to $\mathrm{pH} 5.7$, transferred to a $100.00 \mathrm{~mL}$ volumetric flask and the volume was filled to $100 \mathrm{~mL}$ with water. The chromium(III) was determined under the optimized experimental conditions.

\section{Procedure}

Appropriated aliquot of each sample or standard solution containing chromium ranging from 2.5 to $150.0 \mu \mathrm{g}$ was placed into a $250 \mathrm{~mL}$ beaker and $2.0 \mathrm{~mL}$ of hydroxylammonium solution were added to guarantee quantitative chromium reduction to $\mathrm{Cr}(\mathrm{III})$. Then $10.0 \mathrm{~mL}$ 
of buffer solution, $2.0 \mathrm{~mL}$ of TAR solution and $5.0 \mathrm{~mL}$ of $\mathrm{CTAB}$ solution were added. The volume of the system was filled to approximately $40 \mathrm{~mL}$ with water and placed on the center of the microwave oven. So, the solution was heated up with the microwave oven operating on full power $(700 \mathrm{~W})$ for $5 \mathrm{~min}$ to promote the complexing reaction. After cooling to room temperature, $5 \mathrm{~mL}$ of the complexing solution was added. The resulting solution was placed in a volumetric flask and the volume was filled to $50 \mathrm{~mL}$ with water. The absorbance was measured at $545 \mathrm{~nm}$ in $1.00 \mathrm{~cm}$ glass cells, against a blank prepared in the same way but without chromium.

\section{Results and Discussion}

\section{Characteristics of chromium(III)-TAR complex}

Under the conditions used, chromium(III) ions form a reddish complex with TAR at pH 5.7 with absorption maximum at $545 \mathrm{~nm}$. The absorption maximum of the reagent in the same conditions is at $418 \mathrm{~nm}$. The reaction between TAR and $\mathrm{Cr}(\mathrm{III})$ is too slow at room temperature to be observed. However the absorbance reached its maximum in 4 min and remained stable, at least for $24 \mathrm{~h}$, when the chromium(III)-TAR complex was formed with the aid of microwave energy. In addition, use of CTAB promotes an increase in analytical sensitivity and allows the complex solubilization in aqueous medium.

\section{Effect of the $p H$}

Chromium(III)-TAR system showed a maximal and constant absorbance at $\mathrm{pH}$ ranging from 5.3 to 6.5. An acetate/ acetic acid buffer at $\mathrm{pH} 5.7$ was used to control the medium acidity. The effect of the buffer concentration on the chromium(III)-TAR complex was studied and according to the results no effect in the absorbance signal was observed within acetate concentration raging from 0.10 to $2.5 \mathrm{~mol} \mathrm{~L}^{-1}$. The concentration of $1.0 \mathrm{~mol} \mathrm{~L}^{-1}$ was select for this procedure.

\section{Effect of the surfactant amount}

The results showed that CTAB must be present in the system in a concentration of at least $2.5 \times 10^{-3} \mathrm{~mol} \mathrm{~L}^{-1}$ to avoid precipitation. The presence of the surfactant avoids the use of organic solvent to prevent complex and reagent precipitations. In addition, the presence of CTAB in the system promoted an increasing of $20 \%$ in absorbance signal. It was observed that when this surfactant was present in the range from $2.5 \times 10^{-3}$ to $1.0 \times 10^{-2} \mathrm{~mol} \mathrm{~L}^{-1}$ no effect was observed in the absorbance signal. The concentration of $2.5 \times 10^{-3} \mathrm{~mol} \mathrm{~L}^{-1}$ was select for this procedure.

\section{Composition of chromium(III)-TAR complex}

A study of the complex by mole ratio method showed that TAR forms a 1:2 (metal-to-ligant) complex with $\mathrm{Cr}$ (III). Under the conditions employed, $2.0 \mathrm{~mL}$ of $4.51 \mathrm{x}$ $10^{-4} \mathrm{~mol} \mathrm{~L}^{-1} \mathrm{TAR}$ solution was required to obtain maximal and constant absorbance signal when $3.0 \mu \mathrm{g} \mathrm{mL}^{-1}(3.77 \mathrm{x}$ $10^{-5} \mathrm{~mol} \mathrm{~L}^{-1}$ ) of chromium were used.

\section{Effect of heating with microwave irradiation}

Chromium(III) did not react with TAR at room temperature due to inertness of $\left[\mathrm{Cr}\left(\mathrm{H}_{2} \mathrm{O}\right)_{6}\right]^{3+}$. However, a complex is formed on heating the reactants. Under experimental conditions it was studied the effect of microwave irradiation on the coordination reaction between TAR and $\mathrm{Cr}(\mathrm{III})$. Because the microwave energy in the oven is not uniformly distributed, the location of the beaker with the reational system was the same during experiments. In this way, the beaker was placed on the center of the microwave oven and the solution was heated with the microwave oven operating on full power $(700 \mathrm{~W})$ at different times (1 to $7 \mathrm{~min}$ ). As constant absorbance was recorded on irradiation for $4 \mathrm{~min}$, all determinations were carried after irradiation for $5 \mathrm{~min}$. The complex was stable for at least $24 \mathrm{~h}$.

\section{Effect of the addition order of the reagents}

According to the results obtained, the order of addition of the reagents affects the complex formation. It was observed that the EDTA must be added only after microwave irradiation, when the complex was already been formed in order not to mask the chromium(III) reaction with TAR. Another fact observed relative to the order of addition of reagents is the effect of the hydroxylammonium as a reductant. The hydroxylammonium solution must be always added before the buffer addition.

\section{Effect of interfering ions}

TAR is not a selective reagent for chromium determination. However the mixture of citrate and EDTA as masking agents allowed the spectrophotometric determination with less interference. The effect of this combination on the chromium(III)-TAR complex formation was studied and it was observed that in the concentrations used in the procedure, the mixture did not affect the 
stability of the system for at least $3 \mathrm{~h}$ when it was added after the microwave irradiation.

To study the effect of various metals on the determination of chromium with TAR, a solution containing both chromium and the foreign metal was treated according to the procedure. The reaction selectivity was investigated by determining $25.0 \mu \mathrm{g}$ of chromium in the presence of $2500 \mu \mathrm{g}$ of other ions using the mixed EDTA and citrate complexing solution. The tolerance limit was taken as $\pm 2 \%$ change in absorbance. It was found that for these amounts, $\mathrm{Zn}(\mathrm{II}), \mathrm{Pb}(\mathrm{II}), \mathrm{Ag}(\mathrm{I}), \mathrm{W}$ (VI), Mn(II), Mo(VI), $\mathrm{Si}(\mathrm{IV}), \mathrm{Sb}$ (III), Cd(II), Al(III), Co(II), Cd(II), $\mathrm{Pb}$ (II), Ni(II), $\mathrm{V}(\mathrm{IV}), \mathrm{Zr}(\mathrm{IV}), \mathrm{W}$ (VI), Bi(III) and $\mathrm{Hg}$ (II) did not interfere. Chloride, bromide, iodide, sulfate, nitrate, carbonate, acetate and fluoride did not interfere. The interference of copper was circunvented with addition of thiourea. Fe(III) interfered and must be extracted, as chloride complex, using methyl isobuthyl ketone (MIBK), as previously described.

\section{Application}

In the proposed procedure, Beer's law was obeyed from 0.050 to $3.0 \mu \mathrm{g} \mathrm{mL}^{-1}\left(9.62 \times 10^{-7}\right.$ to $\left.5.77 \times 10^{-5} \mathrm{~mol} \mathrm{~L}^{-1}\right)$, with a molar absorptivity of $2.73 \times 10^{4} \mathrm{~L} \mathrm{~mol}^{-1} \mathrm{~cm}^{-1}$ at $545 \mathrm{~nm}$. The analytical curves were made as described in the experimental procedure and good correlation coefficients $(\mathrm{R}=0.9999, \mathrm{n}=7)$ were found. The detection limit (99.7\% confidence level) and the standard deviation $(\mathrm{n}=10)$ were estimated as $17 \mu \mathrm{g} \mathrm{L}^{-1}\left(3.3 \times 10^{-7} \mathrm{~mol} \mathrm{~L}^{-1}\right)$ and $1.9 \%$, respectively.

The method was applied to chromium determination in steel reference samples and the results are shown in
Table 2. The results, as means of three determinations on each of the four steel samples, were compared with the certified values. The application of the paired $t$-test $(95 \%$ confidence level) did not show significant differences.

\section{Conclusions}

The method using TAR as spectrophotometric reagent to determine chromium in the presence of CTAB is selective, rapid, and simple. Many interferents can be completely masked with EDTA and citrate and the complex showed good stability after microwave irradiation. Fe(III) interfered and must be removed, as chloride complex, using methyl isobuthyl ketone (MIBK). The sensitivity is comparable to other analytical methods allowing chromium determination at $\mathrm{mg} \mathrm{L}^{-1}$ level. The method was successfully applied to determine chromium in steel samples and the results showed good agreement with certified values.

\section{Acknowledgements}

The authors acknowledge the financial support from CNPq, FINEP and CAPES.

\section{References}

1. Othmer, K.; Encyclopedia of Chemical Technology, John Wiley \& Sons: New York, 1981.

2. Boef, G.; Jong, W. J.; Krijn, G. C.; Poppe, H.; Anal. Chim. Acta 1960, 23, 557.

3. Zhao, Y.; Han, G.; Talanta 1994, 41, 1247.

4. Yotsuyanagi, T.; Takeda, Y.; Yamashita, R.; Aomura, K.; Anal. Chim. Acta 1973, 67, 297.

Table 2. Chromium determination in steel reference samples and sample compositions $(\%, \mathrm{~m} / \mathrm{m})$

\begin{tabular}{|c|c|c|c|c|}
\hline \multirow[t]{2}{*}{ Sample composition } & \multicolumn{4}{|c|}{ Steel Sample } \\
\hline & IPT 50 & IPT 17 & IPT 97 & IPT 98 \\
\hline $\mathrm{C}$ & 0.916 & 0.415 & 0.165 & 0.050 \\
\hline $\mathrm{Si}$ & 0.326 & 0.260 & 0.231 & 0.26 \\
\hline $\mathrm{Mn}$ & 0.280 & 0.724 & 1.11 & 1.88 \\
\hline $\mathrm{P}$ & 0.031 & 0.014 & 0.015 & 0.042 \\
\hline $\mathrm{S}$ & 0.015 & 0.021 & 0.026 & 0.016 \\
\hline $\mathrm{Cr}$ & 4.49 & 0.820 & 1.22 & 16.75 \\
\hline $\mathrm{Co}$ & 0.260 & 0.039 & 0.012 & 0.125 \\
\hline Mo & 5.54 & 0.259 & 0.064 & 1.92 \\
\hline $\mathrm{Ni}$ & 0.33 & 1.76 & 0.227 & 11.01 \\
\hline V & 2.00 & - & 0.024 & 0.053 \\
\hline W & 6.40 & - & - & 0.053 \\
\hline $\mathrm{Cu}$ & 0.091 & 0.074 & 0.129 & 0.292 \\
\hline Certified Value $(\mathrm{Cr})$ & 4.49 & 0.820 & 1.22 & 16.75 \\
\hline This $\operatorname{Method}^{\mathrm{a}}(\mathrm{Cr}), \mathrm{n}=3$ & $4.39 \pm 0.07$ & $0.803 \pm 0.02$ & $1.18 \pm 0.02$ & $16.7 \pm 0.2$ \\
\hline
\end{tabular}

a at $95 \%$ level confidence. 
5. Subrahmanyam, B; Eshwar, M. C.; Bull. Chem. Soc. Jpn. 1976, 49, 347.

6. Fu-sheng, W.; Yu-rui, Z.; Pel-hua, Q.; Fang, Y.; Nai-kui, S.; Mikrochim. Acta 1982, 2, 67.

7. Teixeira, L. S. G.; Costa, A. C. S.; Ferreira, S. L. C.; Carvalho, M. S.; Freitas, M.L; J. Braz. Chem. Soc. 1999, 10, 519.

8. Rathaiah, G.V.; Eshwar, M.C.; Bull. Chem. Soc. Jpn. 1985, $58,2447$.

9. Subrahmanyam, B; Eshwar, M. C.; Mikrochim. Acta 1976, $11,579$.
10. Wu, X.; Zhao, H.; Chen, X.; Hu, Z.; Zhao, Z.; Hooper, M.; Anal. Chem. Acta 1998, 374, 61.

11. Zlotorzynski, A.; Crit. Rev. Anal. Chem. 1995, 25, 43.

12. Chen, X.; Xu, Y.; Hu, Z.; Anal. Chem. Acta 1995, 344, 213.

13. Costa, A. C. S.; Assis, J.C.R.; Torres, A. L. C.; Ferreira, S. L. C.; Korn, M.G. A.; Teixeira, L.S.G.; Quim. Nova 1999, 22, 194.

Received: January 27, 2003

Published on the web: November 28, 2003 